\title{
ANNUAL MORPHOLOGICAL VARIATION IN FEMALE REPRODUCTIVE SYSTEM OF SPOTTED SNAKEHEAD CHANNA PUNCTATA (BLOCH, 1793)
}

\author{
Kulsange B.K. and Masram S.C. \\ PGTD of Zoology, RTM Nagpur Unive rsity, Nagpur-440033, India \\ suresh.masram@gmail.com
}

\begin{abstract}
:
Snakehead Channa punctata (Bloch, 1793) is popular food fish. Re productive cycle or breeding cycle of $C$. punctata has five phases viz., resting phase, early maturing phase, prespawning phase, spawning phase and spent phase. Gonadosomatic index (GSI) reveals the period and duration of different phases in reproductive cycle. GSI is maximum during spawning phase while it is minimum in resting phase. Snakehead, C. punctata is annual breeder. Ovary of C. punctata increases its size and shape from resting phase to spawning phase and again reduces its size in spent phase. In diffe rent phases of re productive cycle ovary also changes its color. Resting phase ovary is whitish which become pinkish during early maturing and prespawning phase due to vascularization of ovary. It become transparent and yellowish due to thining of tunica albuginea and underlying yellowish eggs. Smooth contour of ovary be come granular during spawning phase.
\end{abstract}

Key words: Channa punctata, Gonadosomatic index.

\section{Introduction:}

Spotted snakehead, Channa punctata (Bloch, 1793) is highly esteemed as food (Chakrabarti, 2006). All the species of the Channa viz., C. punctata, C. marulius, C. striata and C. gachua bear a pair of folded sac like outgrowth of pharynx called pharyngeal outgrowth to store air (Chakrabarti, 2006). This pharyngeal outgrowth provides these fishes a tenacity to survive outside the water for conside rable period. Reproductive histology can be well investigated by various histological techniques. Ovarian cycle and spawning season of Ophiocephalus punctatus inhabiting Jammu water water was documented (Malhotra et al., 1978) where six stages of oocytes were reported by following method of Srivastava and Rathi (1970). Variation in gonadal cycle, s pawning time and spatial behaviour of this fish were well documented (Swaroop, 1954; Belsare, 1962; Malhotra et al., 1978).

Present study was undertaken to ascertain the breeding cycle, spawning season and to study ovarian morphological changes in $C$. punctata.

\section{Materials and Methods:}

Matured female C. punctata of 150-200 gm weight were collected/procured from various water bodies of eastern Vidharbha. Fishes were acclaimatized in aquaria for one week. After sacrificing fishes, ovaries were dissected out and fixed in Bouin's fluid. After fixation, ovaries were cutted in smaller pieces and cutted pieces of tissues were washed and transferred to $70 \%$ alchohol and dehydrated in graded alcohol, cleared in xylene and embedded in paraffin wax at $60^{\circ} \mathrm{C}-62^{\circ} \mathrm{C}$. Blocks of tissues were trimmed and serial sections of the se blocks were cut on Cambridge (rocking) microtome at 6-8 $\mu \mathrm{m}$ thickness in transverse plane. The sections were fixed on clean slide and later stained by Haematoxylene- Eosine procedure (Lillie, 1965). Sections were observed under Karl Zeiss microscope and photographed by photographed by Tucsen USB $2.0 \mathrm{H}$ series.

Gonado-somatic index (GSI) was used to ensure the different phases of re productive cycle. GSI was calculated by formula:

$$
\mathrm{GSI}=\left(\mathrm{Wg} \times \mathrm{W}^{-1}\right) \times 100
$$

Where:

Wg- Weight of gonads (g), W- Body we ight (g).

Results were expressed as the mean and standard error of mean (SEM). Diffe rence between means were analysed by one-way ANOVA and student T-test. Level of significance was set at $P \leq 0.05$.

Morphological study of ovary was studied after giving midventral cut to abdomen of fish. Dissected fish were photographed by Nikon camera.

\section{Results:}

Paired ovary of C. punctata is suspended from dorsal wall of periotoneal cavity by mesorchium. Two ovarian lobes in C. punctata are of unequal length. The ovarian lobes are of smooth cyclindrical in shape. The ovarian lobes on outer side covered by tunica albuginea (Fig. 1 a).

Based on GSI, morphology of the ovarian lobe and proportion of oocytes present in ovarian lobes, five phases of maturation or reproductive cycle of $C$. punctata were identified.

1. Resting phase (Mid December- February)

2. Early matu ring (March- April)

3. Prespawning (May)

4. Spawning (June- Octo ber)

5. Spent (November- Mid December) GSI in resting phase is $0.58 \pm 0.04$ (Table 1 , graph 1 ). In resting phase, ovary is slender and whitish (Fig.1a). Histologically in resting phase, 
ovary show distinguished ovigerous lamellae hanging in ovocoel (Fig. 2a). Ovige rous lamellae possess primary oogonia, chromatin nucleolus oocyte, early perinuceloar oocyte and few late pe rinucleolar oocytes (Fig. 2a).

Early maturing phase ovary slightly swollen and become pinkish (Fig.1b). Beside primary oogonia, chromatin nucleolus oocyte, early perinucleolar oocyte and late perinucleolar oocyte; vitellogenic oocyte also seen. GSI is early maturing phase increases slightly and is $1.99 \pm$ 0.9 (Table 1, graph 1).

Prespawning ovarian lobe further enlarges become transparent and vascularised (Fig. 1c). His tologically it shows few additional ripe eggs besides the oocytes stage which were seen in early maturing phase (Fig.2c). GSI of prespawning ovary increases further and is 4.49 \pm 0.89 (Table 1, graph 1).

In spawning phase, ovary attains maximum size and outer tunica albuginea become thinner and completely transparent. Smooth contour of ovary look granular due to presence of bulging oocytes (Fig. 1d). In this phase, ovary become highly vascularized (Fig. 1d). His to lo gically ovary show abundant ripe eggs along with other stages of oocytes (Fig.2d). Maximum GSI attained during spawning phase and is elevated to $14.49 \pm 0.73$ (Table 1 , graph 1 ).

In spent phase, ovary become flaccid and thinner (Fig. 1e). During this phase, follicles expel the oocyte thus ovary showed several ovulated follicles. Several atretic follicles were also reported during this phase (Fig. 2e). GSI again lowered down and is $0.60 \pm 0.02$ (Table 1, graph 1).

Table 1: GSI in various phases of breeding cycle.

\begin{tabular}{|l|l|}
\hline Phases & GSI \\
\hline Resting phase & $0.58 \pm 0.04$ \\
\hline Early maturing phase & $1.99 \pm 0.9$ \\
\hline Prespawning phase & $4.49 \pm 0.89$ \\
\hline Spawning phase & $14.49 \pm 0.73$ \\
\hline Spent phase & $0.60 \pm 0.02$ \\
\hline
\end{tabular}

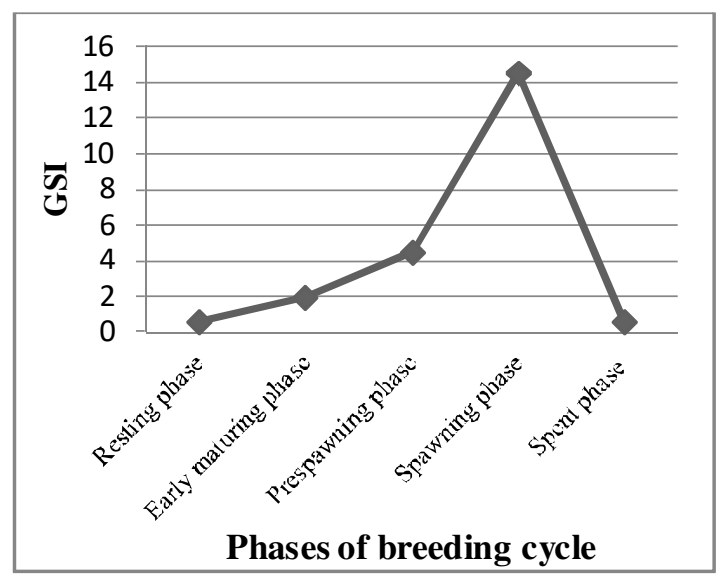

Graph 1: Oscillation in GSI during various phases of breeding cycle

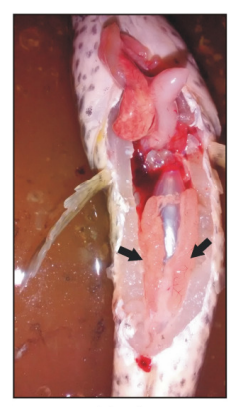

Fig. 1a

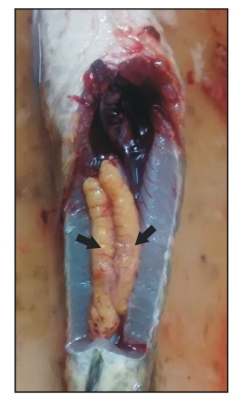

Fig. 1b
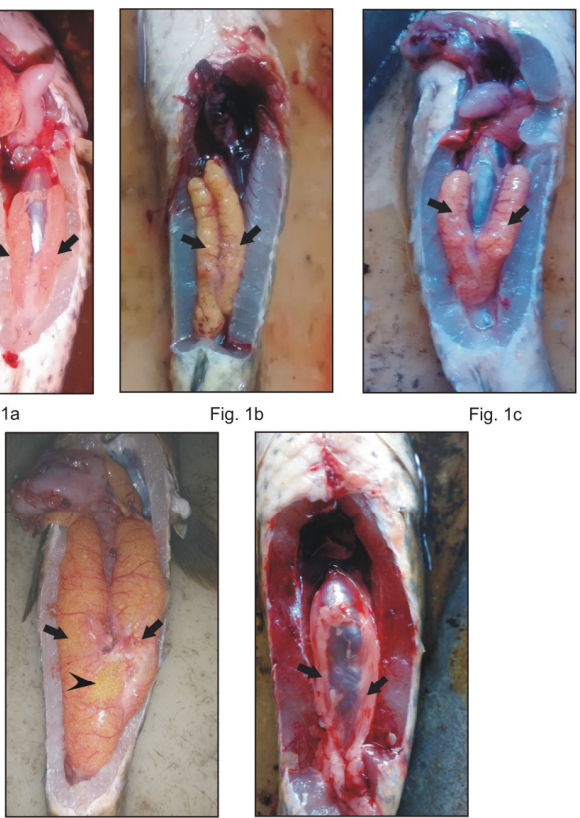

Fig. 1d

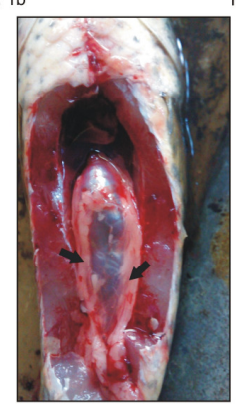

Fig. 1e

Fig. 1 Ovary of C. punctata in various phases of breeding cycle Fig. 1a Resting phase ovary.

Fig. 1b Ovary in early maturing phase.

Fig. 1c Ovary in prespawning phase.

Fig. 1d Ovary in spawning phase showing bulging oocytes (arrowhead).

Fig. 1e Ovary in spent phase. 

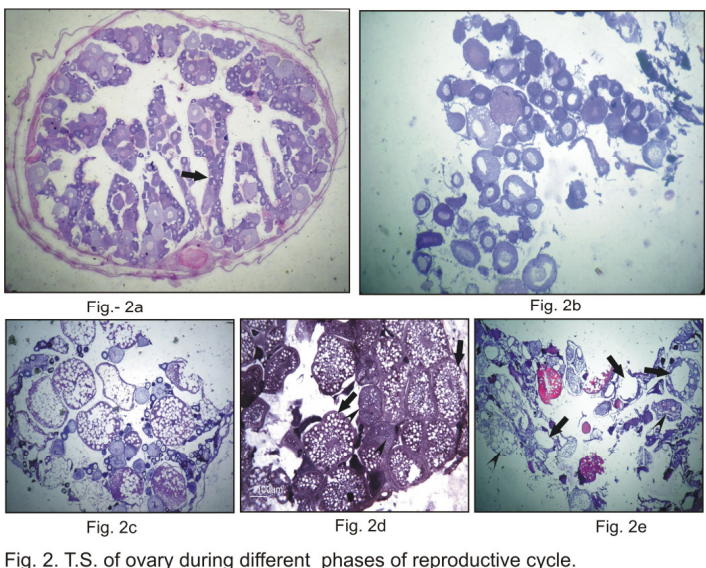

Fig. 2a, T.S. of resting phasc ovary showing ovigcrous lamcllac (arrow) Fig, $2 \mathrm{~b}, \mathrm{~T}$.S. of early maturing phase ovary.

Fig. 2c, T.S. of prespawning phase ovary.

Fig 2d, T.S. of spawning ovary showing numerous ripe oocytes (arrow) along with vitellotgenic and late perinucleolar oocytes (arrowhead). Fig, 2e, T. S. of spent phase ovary showing ovulated follicles (arrow) and atretic follicles (arrowhead).

\section{Discussion:}

In C. punctata, a pair of elongated ovarie s was located in coelomic cavity. Each ovary leads into short oviduct which later opens outside through urinogenital opening. Ovaries from resting phase to spawning phase turn whitish to yellowish in early maturing phase and then become transparent in spawning phase. In spent phase, it looks whitish. Similar result were reported in Carassiums auratus (Munkittrick and Le atherland, 1984), Anabas testudineus (Bahe ra, 2015).Ovary attain maximum size during spawning phase. Similar observations were describe in several cyprinid fishes (Al- Daham and Bahati, 1979; Al-Nouri, 1996; Bardakci et al., 2000).

Symmetry wise, ovaries could be categorized into symmetric and asymmetric ovaryies. Most of the teleostean species exhibit symmetric ovary with similar ovarian lobe. Some teleost show re markable diffe re nce in the length of ovarian lobes. Such ovary represents asymmetric ovaries. Anchoa mitchilli shows asymmetric ovaries (Kobelkowsky, 2012). To ascertain type of C. punctata ovary is difficult task as difference between right and left lobe of ovary is less during the resting and early maturing phase, difference between two lobe became remarkable in spawning phase.

GSI is strongly correlated with gonadal development and maturity of fis h (Rae and Calvo, 1995; Zimmerman 1997; Koya et al., 1998). Maximum GSI was reported during spawning phase. Similar reports were describe in Cynoglossus arel and C. lida (Rajguru, 1992), Potogonotothen tesselata (Rae and Calvo, 1995) and in rainbow trout, Oncorhynchus mykiss (Sharma and Bhat, 2014).

Ovary of C. punctata is asynchronous type as each phase of breeding cycle shows different type of oocytes. Similar asynchronous ovary was reported in Chirostoma hermboldtianum

(Cardenas et al., 2008).

\section{Acknowledgement:}

The author acknowledges UGC, New Delhi for financial ass is tance under Rajiv Gand hi National Fellowship (F-1-17.1/2013-14/RGNF2013-14-ST-MAH-37551 (SA-III/ Website). The author also acknowledges support and facility provided by PGTD of Zoology, RTM Nagpur University, Nagpur.

\section{References:}

Al- Nouri A (1996). Study on the histological changes in the gonads of Acanthobrama marmid infected with Pleroce rcoid of Ligula intestinalis, MSc. Thesis, University of Mosul, 59pp.

Al-Daham NK and Bhatti MN (1979). Annual changes in the ovarian activity of freshwater teleost, Barbus luteus (Heckel) from southern Iraq. Journal of Fish Biology. 14: 381-387.

Bahera S, Monalisa Devi L, Sanjeev Kumar, Gogoi R, Samanta P, Jomang $O$ and Baksi $S$ (2015). External morphology and sexual dimorphism of Anabas testudineus in natural environment. International Journal of Science and Nature, 6(2): 288-292.

Bardekci I, Ozans oy U and Koptage E (2000). Acomparis on of oogenesis under constant and fluctuating temperature in Doctor fish, Garra rufa Heckel, 1843 (Teleostei: Cyprinidae). World wide Web Journal of Biology, 5: 1-7.

Belsare DK (1962). Seasonal changes in the ovary of Ophiocephalus punctatus. Indian Quarte rly Journal of Fishe ries, 9:149-157.

Cardenas R, Chavez M, Gonzalez JL, Aley P, Espinosa J and Jimenez-Garcia LF (2008). Oocyte structure and ultrastructure in the Mexican silverside fish Chirostoma humboldtian um (A the riniformes: Atherinopsidae). International Journal of Tropical Biology, 56(4): 1825-1835.

Chakrabarty NM (2006). Murrels and murrel culture, Narendra Publishing House. New Delhi.

Koya YT, Itazu T, Inque M (1998). Annual reproductive cycle based on histological changes in the ovary of the female mosquitofish, Gambusia affinis in central Japan. Ichthyological Research, 45: 241-248.

Kobelkowsky A (2012). Morphological diversity of the ovaries of the Mexican teleost fishes. International Journal of Morphology, 30(4): 1353-1362. 
Lillie RD (1965). Histopathologic technic and practical histochemistry, 3rd edition, McGrawHill Book Co., New York.

Malhotra YR, Jyoti MK and Gupta K (1978). Ovarian cycle and spawning season of Ophiocephalus punctatus, inhabiting Jammu waters, India. Japanese Journal of Ichthyology, 25(3): 1978.

Munkittrick KR and Leatherland JF (1984). Seasonal changes in the pituitary-gonad axis of feral goldfish, Carassius auratus L., from Ontario, Canada, Journal of F is h Biology, 24: 75 90.

Rae GA and Calvo J (1995). Annual gonadal cycle and reproduction in Patagonotothen tesselata from the beagle channel, Argentina Journal of Applied Ichthyology, 11: 60-70.

Rajaguru A (1992). Biology of two co-occurring tonguefishes Cynoglossus arel and C. lida
(Pleuronectiformes: Cynoglossidae), from Porto Nova, southeast coast of India. Fishery Bulletin, 90: 328-367.

Sharma RK and Bhat RA (2014). Histoarchitectural variations during oocyte growth in rainbow trout (Oncorhynchus mykis). International Journal of Fisheries and Aquatic Studies, 2(2): 177-183.

Shrivastava PN and Rathi SK (1970). Effect of radiation on reproductive system of Indian catfish Heteropneustus fossilis Bloch. I. Annual cycle in development of reproductive tissue of Mugil cephalus L. Zoolo gia, 44: 53-70.

Swaroop H (1954). The development of chondrocranium of Ophiocephalus punctatus. Sang University Journal, 1:61-79.

Zimmermann M (1997). Maturity and fecundity of arrow to oth flounder, A theresthes stomias from the gulf of Alaska. Fish Bulle tin, 95, 598-611. 